\title{
Studi Konsep Pengaruh Kualitas Pelayanan Terhadap Kepuasan Pelanggan di PT. PLN (Persero) Sebagai Perusahaan Penyedia Energi Listrik Monopoli
}

\author{
Widyana Verawaty Siregar, Syarifah Muthia Putri \\ Fakultas Teknik Manajemen, Fakultas Ekonomi dan Bisnis, \\ Universitas Malikussaleh \\ Jl. Cot Tengku Nie, Reuleut, Muara Batu, Aceh Utara, Indonesia Telp. + (62) 645.41373 \\ e-mail: widyana.verawaty@unimal.ac.id
}

\begin{abstract}
Abstrak - Salah satu parameter yang digunakan pelaku bisnis untuk mengukur kinerjanya adalah melalui kualitas layanan. Dalam tulisan ini, dijelaskan konsep pengaruh kualitas pelayanan terhadap kepuasan pelanggan pada PT. PLN (Persero) yang menyediakan energi listrik kepada konsumen. Selain itu juga melihat faktor kualitas pelayanan yang turut berperan dalam menjelaskan kepuasan pelanggan pada perusahaan. Hasilnya menunjukkan bahwa tingkat kualitas pelayanan yang telah diberikan kepada pelanggan sangat mempengaruhi kepuasan pelanggan. Juga menunjukkan perlunya sosialisasi kepada karyawan perusahaan bahwa pelanggan perlu mendapat perhatian penuh sebagai klien atau pelanggan yang membeli produk dan jasa perusahaan.
\end{abstract}

Kata kunci : kualitas pelayanan, kepuasan pelanggan, PT. PLN (Persero)

\begin{abstract}
One of the parameters used by business people to measure their performance is through service quality. In this paper, the concept of the influence of service quality on customer satisfaction at PT. PLN (Persero) which provides electrical energy to consumers. In addition, it also looks at the service quality factors that play a role in explaining customer satisfaction at the company. The results show that the level of service quality that has been provided to customers greatly affects customer satisfaction. Also shows the need for outreach to company employees that customers need to get full attention as clients or customers who buy company products and services.
\end{abstract}

Keywords : $\quad$ service quality, customer satisfaction, PT. PLN (Persero)

\section{PENDAHULUAN}

Kualitas layanan penting bagi kalangan bisnis untuk memastikan keberlangsungan roda bisnis perusahaan dan untuk mempertahankan daya saingnya. Banyak keuntungan yang didapat jika dalam kualitas layanan terhadap konsumen itu baik. Ini sangat terkait terhadap kepuasan pelanggan, loyalitas, pembelian berulang, dan keuntungan jangka panjang melalui promosi mulut ke mulut yang positif. Selain itu, perusahaan yang memberikan layanan berkualitas baik akan mendapatkan penghematan dari sebi biaya penanganan kesalahan. Perusahaan monopoli seperti PT. PLN (Persero) sebagai penyedia energi listrik akan menghadapi ketidakpuasan pelanggan karena ada peningkatan konsumsi [1]. Selain itu, aspek khas dari bisnis penyedia energi listrik ini adalah memastikan pasokan yang andal dan waktu layanan yang tepat [2] dengan selalu mengedepankan tingkat keselamatan.

Perusahaan listrik negara di Indonesia termasuk dalam usaha yang monopoli karena merupakan satusatunya perusahaan yang menyediakan listrik untuk konsumen yang langsung kemasyarakat. Sebagai perusahaan monopoli, perusahaan menikmati beberapa keuntungan seperti kurangnya persaingan. PT. PLN (Persero) tersebut merupakan merupakan peruhaan perseroan yang diprivatisasi pada dan menjadi BUMN meskipun masih merupakan perusahaan yang terkait dengan pemerintah.

'Namun, pihak perusahaan tidak bisa mengabaikan aspek kualitas layanan meskipun perusahaan merupakan satu-satunya penyedia listrik. Oleh karena itu, aspek kualitas layanan bisnis ini, proses yang meliputi tiga rangkaian kejadian yaitu proses sebelum, selamam dan setelah layanan yang diberikan kepada pelanggan perlu ditinagkatkan. Mengingat masih terbatasnya studi tentang kualitas layanan perusahaan yang bersifat monopoli, terutama yang berstatus BUMN, maka studi ini bermaksud untuk memahami fenomena tersebut. Dengan demikian, penelitian ini menggunakan lima dimensi SERVPERF dengan dimensi recoveryability yang lain untuk menentukan tingkat kualitas layanan yang ditawarkan kepada pelanggan dan untuk mengidentifikasi hubungannya dengan kepuasan pelanggan. Juga disajikan beberapa rekomendasi bagi manajer untuk meningkatkan layanan mereka. 


\section{TINJAUAN PUSTAKA}

Kajian tentang kualitas layanan telah mendapatkan momentumnya sejak pertama kali disebutkan pada akhir 1980-an. Penulis seperti Cronin dan Taylor, Groonros, Parasuraman, Zeithmal dan Berry, serta Rust dan Oliver adalah beberapa nama terkenal di bidang ini. Mereka telah menyarankan beberapa model yaitu SERVQUAL, SERVPERF, dan PARKSERV untuk mengukur tingkat kualitas layanan pelanggan. Meskipun demikian, mereka merekomendasikan bahwa setiap model kualitas layanan yang digunakan harus disesuaikan dengan industri yang dilayani. Ini karena setiap industri memiliki karakteristik uniknya masing-masing. Selain itu, persepsi pelanggan terhadap tingkat layanan yang ditawarkan akan berbeda.

Perusahaan-perusahaan di industri penyedia energi listrik dihadapkan pada tuntutan dan permasalahan yang berbeda. Kemampuan perusahaan dalam mensuplai energi listrik, proses dalam mensuplai listrik, termasuk frekuensi pemadaman, dan kinerja pelayanan tenaga listrik merupakan beberapa faktor yang mempengaruhi kualitas suatu perusahaan penyedia energi listrik [1] [3]. Sebelumnya, banyak pelangan yang tidak puas di industri yang menyatakan layanan yang tidak karena tidak ada saluran bagi mereka untuk menyuarakan pendapatnya. Dengan kemajuan teknologi, pelanggan menjadi sensitif dan akibatnya menuntut layanan yang lebih baik.

Sebagian besar studi tentang kualitas layanan berfokus pada industri perhotelan [4], ritel [4] [5], sektor pendidikan [6], telekomunikasi [2], dan pabrik layanan [7]. Beberapa penulis yang telah melakukan penelitian pada industri penyedian energi listrik yang berfokus pada benchmarking kualitas layanan [3], penerimaan harga [8], transmisi dan jaringan [9], perilaku manajemen [10], dan evaluasi aspek kualitas layanan [1]. Studi-studi sebelumnya kurang menekankan pada situasi di mana pelanggan dapat melindungi perusahaan untuk transaksi lebih lanjut, maka dalam studi ini mencoba untuk memenuhi kebutuhan dalam memahami pengalaman pelanggan.

Selain itu, studi tentang perusahaan penyedia energi listrik di Indonesia ini perlu dilakukan karena sifat persaingan yang terbatas. Ini terutama karena pelanggan tidak mungkin beralih ke perusahaan penyedia energi listrik yang lain. Lebih lanjut, kepuasan pelanggan tidak tercermin dalam keuntungan perusahaan [8], terutama ketika perusahaan memiliki pendekatan altruisme sosial [11]. Oleh karena itu, terdapat kecenderungan perusahaan mengabaikan faktor peningkat kualitas. Selain itu, studi menunjukkan bahwa privatisasi tidak meningkatkan kualitas layanan untuk industri yang sama [10].

\section{METODE}

Data dikumpulkan secara acak menggunakan kuesioner yang dikelola sendiri kepada pelanggan. Skala Likert 5 poin berkisar dari "1" (sangat tidak setuju) hingga "5" (sangat setuju). Pengambilan sampel acak sederhana digunakan untuk menyebarkan kuesioner.

SERVPERV dipilih sebagai dasar untuk penelitian ini karena penulis sebelumnya telah membahas kesesuaian instrumen ini dibandingkan dengan SERVQUAL [12] [13]. Hal ini penting karena SERVQUAL memerlukan analisis kesenjangan untuk menentukan tingkat kualitas layanan. Untuk menangkap pengalaman komprehensif, dimensi lain yang diusulkan oleh Oloruninwo ditambahkan ke instrumen [6]. Terdapat 27 item yang mewakili 6 dimensi kualitas layanan, yaitu: tangibility, reliability, responsiveness, assurance, empathy, dan recoverability.

Dalam mengoperasionalkan variabel, patut diadaptasi pertanyaan serupa yang digunakan dalam literatur sebelumnya. Wujudnya mengacu pada kebersihan, pengaturan tempat duduk, peralatan, dan tempat parkir sedangkan keandalan mengukur keakuratan, keamanan informasi, dan pelayanan yang benar. Daya tanggap mencerminkan sikap staf, ketersediaan staf, dan umpan balik oleh staf. Di sisi lain, kepastian mencerminkan keamanan transaksi, karyawan yang berpengetahuan luas, dan kepercayaan. Empati menunjukkan perhatian yang diberikan oleh staf dan memahami kebutuhan pelanggan. Sementara itu, pemulihan menunjukkan kesediaan staf untuk menerima kesalahan, cara staf menangani keluhan, dan diberdayakan untuk mengambil tindakan. Item pada tangibility mencerminkan pengalaman pelanggan sebelum layanan dilakukan sedangkan item yang mencakup keandalan, daya tanggap, jaminan, dan empati mencerminkan pengalaman pelanggan selama pemberian layanan. Akhirnya, item yang digunakan untuk mengukur "efek samping" dari pemberian layanan dikenal sebagai kemampuan untuk dipulihkan.

\section{HASIL DAN PEMBAHASAN}

Untuk memahami kekuatan prediksi setiap dimensi dengan kepuasan pelanggan, dilakukan uji regresi berganda. R-square yang disesuaikan untuk model ini menunjukkan bahwa kepuasan pelanggan dijelaskan oleh model. Semua variabel yang dibangun untuk model ini, yaitu tangibility, reliability, 
responsiveness, assurance, empathy, dan recoverability, memiliki hubungan yang signifikan dengan kepuasan pelanggan. Assurance memberikan kontribusi dalam menjelaskan kepuasan pelanggan, diikuti oleh pemulihan. Jelas, meyakinkan pelanggan ditingkatkan dengan elemen pemulihan yang menunjukkan "kemampuan untuk mengendalikan situasi" [6]. Dengan demikian, keduanya memberikan kontribusi yang besar untuk menjelaskan kepuasan pelanggan di industri tersebut.

Hasilnya menunjukkan bahwa tangibility memiliki nilai yang signifikan dalam menjelaskan kepuasan pelanggan. Hasil ini juga menunjukkan bahwa layanan berwujud yang disediakan oleh organisasi dapat mempengaruhi kepuasan pelanggan dalam mengunjungi tempat tersebut. Perusahaan memberikan kemudahan bagi pelanggan yang harus berurusan langsung dengan penyedia layanan. Meskipun variabel penting dalam studi kualitas layanan, literatur sebelumnya setuju bahwa sifat fisik bukan faktor utama dari elemen kualitas dibandingkan dengan daya tanggap dan pemulihan [5] [13].

Reliabilitas juga merupakan salah satu faktor pendukung yang menjelaskan kepuasan pelanggan. Perusahaan mampu memperoleh kepuasan pelanggan melalui keandalan layanannya. Penting bagi pelanggan untuk merasa aman dengan informasi pribadi yang diberikan kepada organisasi, terutama jika menyangkut transaksi moneter [14] [15].

Responsiveness mengacu pada kesediaan untuk membantu pelanggan serta memberikan layanan yang cepat kapanpun diperlukan [14]. Pelanggan merasa bahwa karyawan organisasi selalu siap melayani pelanggan. Ini sejalan dengan peneliti sebelumnya yang berpendapat bahwa responsivitas dapat mempengaruhi kualitas layanan yang diberikan oleh organisasi. Variabel ini juga menunjukkan bahwa sangat mungkin untuk memprediksi kepuasan pelanggan di industri retail [4]. Studi lain di industri penerbangan mengungkapkan bahwa responsivitas adalah elemen kualitas utama yang berkontribusi terhadap kepuasan pelanggan.

Kepastian adalah dimensi lain dari kualitas layanan yang muncul dengan hasil yang serupa. Banyak ahli menemukan bahwa variabel ini adalah salah satu elemen terpenting dalam kualitas layanan [4] [5] [16]. Dalam industri ritel, jaminan layanan tercermin dari ketepatan layanan, kecepatan layanan, dan akurasi transaksi [15].

Empati berfokus pada kebutuhan pelanggan. Pelanggan merasa bahwa karyawan organisasi berorientasi pada pelanggan dan bersedia membantu pelanggan kapan pun dibutuhkan. Namun, tingkat kepuasan terhadap empati di antara pelanggan mungkin berbeda antar industri. Sebagian besar industri percaya bahwa empati adalah elemen kualitas yang penting dan sangat rumit untuk ditangani [14].

Variabel terakhir yang digunakan dalam adalah kemampuan pemulihan. Dapat dipulihkan mengacu pada kemampuan untuk mengendalikan situasi ketika ada kendala atau gangguan sistem. Jelas, pelanggan merasa bahwa karyawan pada PT. PLN (Persero) mampu menangani pengaduan dengan baik. Kemampuan karyawan untuk menanggapi permintaan pelanggan dan menangani keluhan tampaknya menjadi faktor penting dalam industri berorientasi layanan dan dengan demikian menyampaikan citra organisasi yang baik [14].

\section{KESIMPULAN}

Studi ini menganalisis konsep kepuasan pelanggan dengan layanan yang diberikan oleh perusahaan penyedia energi listrik yang bersifat monopoli. Tujuannya adalah untuk mengetahui tingkat kualitas layanan yang ditawarkan dan hubungannya dengan kepuasan pelanggan. Penjelasannya menunjukkan bahwa secara keseluruhan, responden "setuju" tentang kepuasan layanan yang diterima sebelum layanan dilakukan (dimensi tangibility), selama pemberian layanan (dimensi: keandalan, daya tanggap, jaminan, dan empati), dan setelah efek dari layanan (dimensi pemulihan). Di antara semua variabel, jaminan membawa kontribusi terberat diikuti oleh pemulihan, keandalan, empati, daya tanggap, dan sifat nyata. Oleh karena itu, penyedia layanan energi listrik seperti PT. PLN (Persero) harus memasukkan elemen-elemen ini dalam program pelatihan karyawannya elemen tersebut penting untuk kepuasan pelanggan.

Privatisasi perusahaan berarti pemerintah mengalihkan jasanya kepada perusahaan swasta dan bukan berarti liberalisasi ekonomi yang membuka sistem persaingan. Dengan demikian, harapan pelanggan terhadap kinerja perusahaan monopoli terbatas pada pelanggan perusahaan. Karena jaminan memiliki nilai tertinggi dalam menjelaskan kepuasan pelanggan, organisasi harus mempertimbangkan elemen ini saat menyusun program pelatihan karyawan mereka.

\section{DAfTAR PUStaka}

[1] S. Satapathy, S. K. Patel, S. S. Mahapatra, G. S. Beriha, and A. Biswas, "Service quality evaluation in electricity utility industry: an empirical study in India," Int. J. Indian Cult. Bus. Manag., vol. 5, no. 1, pp. 59-75, 2012. 
[2] Y. Wang, H.-P. Lo, and Y. Yang, "An integrated framework for service quality, customer value, satisfaction: Evidence from China's telecommunication industry," Inf. Syst. Front., vol. 6 , no. 4, pp. 325-340, 2004.

[3] J. Njoroge, "Power quality in the competitive market: The customer perspective on monitoring, reporting and benchmarking of service quality," in CIRED 2005-18th International Conference and Exhibition on Electricity Distribution, 2005, pp. 1-4.

[4] C. N. K. Naik, S. B. Gantasala, and G. V Prabhakar, "Service quality (SERVQUAL) and its effect on customer satisfaction in retailing," Eur. J. Soc. Sci., vol. 16, no. 2, pp. 231-243, 2010.

[5] F. Pakdil and Ö. Aydlin, "Expectations and perceptions in airline services: An analysis using weighted SERVQUAL scores," J. Air Transp. Manag., vol. 13, no. 4, pp. 229-237, 2007.

[6] F. Olorunniwo, M. K. Hsu, and G. J. Udo, "Service quality, customer satisfaction, and behavioral intentions in the service factory," $J$. Serv. Mark., 2006.

[7] Z. Zakaria, A. Ahmad, and M. Norzaidi, "Determining World Class University from the evaluation of service quality and students satisfaction level: An empirical study in Malaysia," Int. J. Sci. Res. Educ., vol. 2, no. 2, pp. 59-66, 2009.

[8] G. Rekettye and J. Pinter, "Customer satisfaction and price acceptance in the case of electricity supply," Int. J. Process Manag. Benchmarking, vol. 1, no. 3, pp. 220-230, 2006.

[9] H. Landrum and others, "Measuring Information Science System Service Quality with SERVQUAL: Users' Perceptions of Relative
Importance of the Five SERVPERF Dimensions," Inf. Sci. Int. J. an Emerg. Transdiscipl., vol. 12, pp. 18-34, 2009.

[10] E. Fumagalli, P. Garrone, and L. Grilli, "Service quality in the electricity industry: The role of privatization and managerial behavior," Energy Policy, vol. 35, no. 12, pp. 6212-6224, 2007.

[11] N. H. A. Razak, R. Ahmad, and H. A. Joher, "Does government linked companies (GLCs) perform better than non-GLCs? Evidence from Malaysian listed companies," J. Appl. Financ. Bank., vol. 1, no. 1, pp. 213-240, 2011.

[12] L. L. R. Rodrigues, G. Barkur, K. V. M. Varambally, and F. G. Motlagh, "Comparison of SERVQUAL and SERVPERF metrics: an empirical study, The TQM Journal 23 (6): 629-643." 2011.

[13] S. K. Jain and G. Gupta, "Measuring service quality: SERVQUAL vs. SERVPERF scales," Vikalpa, vol. 29, no. 2, pp. 25-38, 2004.

[14] K. Ravichandran, B. T. Mani, S. A. Kumar, and S. Prabhakaran, "Influence of service quality on customer satisfaction application of servqual model," Int. J. Bus. Manag., vol. 5, no. 4, p. 117, 2010.

[15] N. Nasirun, S. M. Noor, Z. M. Nor, H. Ahmat, and Z. Ahmad, "Perceived web service quality for students' portal in higher learning institution," Int. Proc. Econ. Dev. Res., vol. 56, p. 52, 2012

[16] S. M. Noor and N. Nasirun, "Service Quality and Customer Satisfaction in a Natural Monopoly Company," in Proceedings of the Colloquium on Administrative Science and Technology, 2015, pp. 61-68. 